\title{
High Elementary Teachers' Estimations in Ajloun Governorate about the Role of School Curricula in Enhancing Woman's Image in the Jordanian Community
}

\author{
Mohareb Ali Alsmadi, Mohammad Omar Al-Momani* \\ Department of Science of Education, Ajloun University College, Al-Balqa Applied University, Jordan
}

Received March 17, 2020; Revised May 19, 2020; Accepted June 24, 2020

Copyright $\odot 2020$ by authors, all rights reserved. Authors agree that this article remains permanently open access under the terms of the Creative Commons Attribution License 4.0 International License

\begin{abstract}
The curricula in more than one way shape the behavior and beliefs of students, and thus society, so the stereotypical image of women in society may be related to the image of women presented in the curricula. The present study aimed at investigating male and female teachers' assessments of the role of school curricula in enhancing the image of women in the Jordanian society. To achieve the objectives of the study, the descriptive survey method was used. The researcher developed a questionnaire consisting of (61) paragraphs covering seven fields. The sample of the study consisted of (201) male and female teachers. The results showed that the school curricula contributed in a moderate level in improving the image of women among members of Jordanian society in the following fields: Attitudes in presenting women's s image and Women environment. The results also revealed that the role of the curricula was below average in the following fields: Jordanian curricula role in the higher basic stage in encouraging the woman in politic work; Domains of women's work, the role of higher basic stage curricula role in clarifying the woman's legal and professional equality with man, Domains of women's work. The results also showed that there are no statistically significant differences in the teachers' estimation of the role of the curricula in improving the image of women in Jordanian society, according to the gender variable. On the other hand, the study revealed that there were no statistically significant differences in the estimation of male and female teachers due to the variables of teaching experience and educational qualification.
\end{abstract}

Keywords Jordanian Curricula, Woman, Content, Activities

\section{Introduction}

\subsection{Overview}

The social and educational system usually cares about the emotional and social structure of the individual by his/her objectives and needs related to his/her philosophy within his/her suitable social and educational organizations. The social system dominates the educational policies in particular and the educational curricula by identifying its objectives and the knowledge that covers such purposes. Besides, it limits the values in different social environments and delivers the knowledge and spreads it out socially. The curriculum reflects the ideology which the society believes in. Therefore, policymakers care about the values and attitudes presented in the textbooks.

Identifying the values and attitudes in society is essential to choose the kind of knowledge that decision-makers want to present. Therefore, choosing the right values in the curricula helps to form the minds of learners to show positive social models.

Any serious academic study about the woman should begin by identifying different common and familiar pictures about her in the community to judge whether such images represent the reality of woman to push up what is good and leave out the negative or incorrect pictures about her because such pictures might distort her and be genergized by being dealt with among people.

What helps us in identifying such pictures is the study of those pictures in the school curricula because it represents the people's perspective of woman according to the social values and attitudes such pictures include.

The school is important because it is the primary institution for extended education in the child's life that 
pushes forward toward change through the school curricula and textbooks and the role of teachers. In the last ten years, the educational system in Jordan has been comprehensively developed to cope up with the local and world-changing and challenging. The school curricula and textbooks have been comprehensively changed in particular in the essential stage. The national committee for woman affair made a great effort to achieve equality between men and women. One crucial national strategic objective for the woman was increasing the effectiveness of the educational system by presenting positive pictures for the woman's position in the community and within the family in assuring her role in social development.

The initiation of the Jordanian center for social research in cooperation with the United Nations developmental funding - western Asia office - and UNESCO did a comprehensive survey to identify the real roles that the textbooks in the primary stage present to contribute to completing the modernization process.

\subsection{Politic and Social Participation Pictures for the woman in the Arab World}

Nowadays, there is an assurance for the role of women in equality and development. The world attitude focuses on the assessment procedures and the social legislations that treat the role of woman and her social rank. Besides, a significant concern is for emerging the programs related to woman in the sustainable developmental plans mainly including human development by considering the following: (Fahmi, 2003)

1. The woman is socially productive, having material and social inputs and outputs.

2. She had a parallel perspective for woman: productive and human. The woman has two levels: self -as working for herself and socially.

3. The Arab woman's situation is affected by Islamic legislation and other different opinions, which is the most dangerous.

For enhancing the participation mechanisms for women socially and politically, it is essential to shed light on her position in different Arab world countries and how she is empowered. Lauren (1995) defined woman's empowering as "the process through which the woman's abilities are increased to make strategic life choices in the time those choices were exclusive to others". Such participation was represented in the following areas(UNESEF, 1999): 1. education 2 . health 3 . job 4 . politics 5 . future plans for woman's development.

\subsection{Pictures of Social and Political Participation of woman in Jordan (Shetewi \& Al Daghistani, 1994; Kabeer, 1999)}

- Education: The educational system in Jordan has been distinguishedly developed in particular in raising the woman's educational level, where illiteracy rates became less for females. In 1979 the percentage decreased to (49.5\%), and in 1991 it reached $(25 \%)$. The percentage of female students in all educational stages was higher and higher. and in 20181, it reached (7.2\%) (Department of Statistics, 2018).

- Health care: The health care services in Jordan witnessed significant development, which reflected on the health position for a woman. The average female age raised from 64 years in 1980 up to 68 in 1992. However, it increased for females by 0.9 years (75.1 years in 2018 and 74.2 years in 2017) (Department of Statistics, 2018).

- Jobs: The Jordanian woman worked in different domains and public sectors. Besides, she worked in general management, teaching, health care, social work, agriculture, industry, and in various social activities, some of them had got their own businesses.

- Politics: The woman shared in the parliament, in the government as a minister for the social development in 1979, for the information in 1984, and for the industry and trade in 1993. In addition, she shared in the inferior affairs as an ambassador. Locally the woman shared in the counseling councils in 1990. As in the higher general management, she had good participation.

- Woman Future Plans: The work government plan included the following:

1) Increasing the woman's contribution to economic activity and enhancing her participation.

2) Educating the woman about her legal rights and duties and seeking for developing the laws that implied the woman's political, social, and cultural rights the Islamic religion offered her and assured her rights in education and work.

3) Developing the woman's contribution to political life.

4) Enhancing the positive picture for woman and improving the education services to improve her contribution in public life to develop her creative abilities.

5) Developing health care services in general and the family health care services, in particular.

6) Enhancing the woman's participation in preparing and carrying out the plans and programs related to the environment. In addition, providing environmental education and awareness.

7) Enhancing the role of media to serve the woman's issues and her role in the family and the community. In addition, empowering woman to contribute effectively in preparing TV and Radio programs to raise the woman's position and to make her role in developmental domains clearer. 


\subsection{Problem of the Study}

This study follows up the role of limitation that the higher basic stage curricula have in enhancing the woman picture in the Jordanian community. The study checks whether such curricula in the Jordanian schools reflected the newly developed position for woman or those textbooks present a typical traditional picture for the woman's role and rank in the community. Does that picture of the woman in the Jordanian curricula respond to the demands of development in the Jordanian community or is there a big gap between the reality and that picture in the curricula? Such demanded pictures should be originated from the educational philosophy in the woman's pictures to achieve the serious demanded ambition of development and change.

Because the woman's role has become exactly as the man's in developing her abilities and skills in all domains of social economic cultural and political life to be able to contribute to the progress of the community. This study tries to follow up the role of the ministry of education that it could play in the school curricula in modifying the Jordanian woman's picture for the community. This could be achieved by identifying the woman's picture in the current school curricula.

The researchers point out that school is the best way for our children to know about the new role of woman in the community. Because the role of the school is really positive and effective in finding out a solution for the problems in the community and working on changing the basic values of the community. In this respect, the school could really be the pioneer in social change.

\subsection{Research Question}

The present study aimed at investigating male and female teachers' assessments of the role of school curricula in enhancing the image of women in Jordanian society. This study is also aimed to answer the research questions stated below:

1. What are the estimations of the higher basic stage teachers in the governorate of Ajloun for the role of the higher basic stage in enhancing the woman's picture for the Jordanian community?

2. Are the estimations of higher basic stage teachers in the governorate of Ajloun for the role of higher basic stage curricula in enhancing the woman's picture for the Jordanian community different according to (sex, number of years of teaching experience, educational qualification)?

\section{Literature Review}

Abu-Ayyash (2019) the aim of this paper is to describe and analyze the image of woman in the new Palestinian Arabic language curriculum for Basic Elementary Stage
(Classes 1-4) as a model. The study found that the Palestinian curriculum is insensitive to gender issues and reinforces the classical/traditional stereotyped image of woman. This is clear in the weak representation of women in general, and in her absence in approximately $40 \%$ of texts and images. In addition, even the modest presentation of woman does not reflect the reality of the Palestinian woman or her contributions and ambitions on any of the social, economic, cultural, and political levels.

Gadri, R., et al (2015) aimed to discuss women images in grade eight textbooks in Palestinian schools. The researchers used three main tools to collect the required data; the content analysis tool was developed for the purpose of analyzing the targeted textbooks (Arabic, Science, Math, and social studies) from a gender point of view. The pictures, language, roles, and responsibilities of males and females in the textbooks were noticed and analyzed. 15 Semi-structured interviews were conducted with teachers in different schools and classes were observed. The study found that the participation of female authors in textbooks authors is less than the participation of males. The stereotyped image of women is still reflected in the textbooks with a slight improvement in Arabic textbooks. The study recommended that more training workshops for teachers in gender awareness should be conducted.

Sarabi (2010) aimed at investigating the image of women in Jordanian textbooks for the first and sixth grades. The content analysis approach was used for analysis. The study sample consisted of the content of books (Arabic, national and civic education, social and national education, science, and mathematics). The study showed that the literary, scientific, philosophical and heroic works of women have been ignored, while the role of men has become clear in these areas.

Omran (2008) conducted another study aimed at investigating the woman's picture in Saudi Arabia curricula by analyzing the content of some textbooks which included the reading texts, songs, composition and behaviors, the history textbook for all stages, the textbooks of literary texts, Hadeeth Shareef, Fiqh in the medium and secondary stage. The findings showed many obstacles in raising the role of woman in the community because of the unawareness of the woman's rank, which reflected the man's superiority in parallel with no appreciation for the woman.

ALKhaldi (2004) conducted a study aimed at investigating the role of Jordanian applied school textbook in $(2003$ / 2004) in empowering the Jordanian woman. For achieving the objective of the study, the researcher used the interview and analyzed the data. The sample consisted of (23) participants. Purposeful the findings showed that such textbooks do not include Jenderalism culture (the acts both sexes express their social quality through), which seeks to enhance the woman's self-sufficiency and choosing the educational content topics to meet the girls' needs. Also, 
there were paradoxical topics in the content about the woman, and some texts included in the study do not reflect an organized translation in the planning level and in structuring the curricula.

We see through showing the past studies that it reassures the traditional role of woman in the curricula and textbooks, in spite of the difference in the time the studies were made in, as well as the size, the comprehensive sample study, and the accurate method used. Yet, most studies in these books were studying and analyzing the woman's image without man. Besides, they were obviously poor on a theoretical and methodical basis.

The results of the study as a whole, were emphasizing on the role of woman as a mother and daughter, Abu-Ayyash (2019) ; Gadri, R., et al (2015); Sarabi (2010) ; Omran (2008); ALKhaldi (2004)

What differentiated this study from the other ones is that it's trying to discover the roles the school curricula play to improve the woman's image in the society through the teacher's estimations for the curricula's role in enhancing this image in the Jordanian society, which was neglected in the past studies that depended on curricula analysis, excluding study (Al Khalidy, 2004; Omran, 2008).

After reviewing the related studies, it was clear that most of it assured the traditional woman's role in the school textbooks and curricula in many Arab countries in the time those studies were conducted. What makes this study significant is the attempt to investigate the Jenderalism roles (male and female) and not exclusive for the woman's image. In addition, the sample in this study is comprehensive for all the curricula of the basic stage. Moreover, there was an analysis for the used language in the school curricula to find out the Jenderalism dimension.

Through these studies, the researchers conclude that the image formed about woman is completely different from the man's, meaning while the woman took the minor, that included the professional side, political work, and legal rights.

The importance of this study arises from the fact that this study is concerned with the formation of student's attitudes towards the woman in the school textbooks. In addition, to achieve social equality, the school textbooks should focus on the way women are represented.

The school curricula are considered an instrument of changing the attitudes of the community and solving the problems that communities face. Therefore, revising the curriculum is a progressive process seeking for generating new knowledge and beliefs. In this respect, this study investigated the role of school curricula in enhancing the woman's picture for the Jordanian community. The present study sheds light on woman and how it is represented in the higher basic stage in the academic year $(2018 / 2019)$.

In addition, this study is significant because its findings may benefit those in concern with the analysis and assessment of Jordanian curricula. Moreover, the study may help curricula planners and executives to reinforce the strong points and put mechanisms and plans to treat the weak points found in the curricula.

\section{Methodology}

The descriptive survey method was used to achieve the study objectives.

\subsection{Population of the Study}

The population includes all male and female teachers in the governorate of Ajloun who were (679). The formation was taken from the directorate of education in Ajloun governorate.

\subsection{The Sample of the Study}

The sample consisted of (201) teachers in Ajloun governorate. It was chosen randomly in a percentage of $(30 \%)$ from the study population; Abu Odeh (2010) indicated that in the case of medium populations (500-1000), it is appropriate to choose a sample that is not less than $20 \%$ of the total size of the population. Thus, the sample of the study consists of $30 \%$ of the population.

Table (1) shows the distribution of the sample of the study according to the independent variables.

Table 1. Frequencies and Percentages for the Sample of the Study According to its Variables

\begin{tabular}{|c|c|c|c|}
\hline $\begin{array}{c}\text { Independent } \\
\text { variables }\end{array}$ & Categories & Frequency & Percentage \\
\hline Sex & $\begin{array}{c}\text { Male } \\
\text { Female }\end{array}$ & $\begin{array}{c}110 \\
91\end{array}$ & $\begin{array}{l}54.7 \\
45.3\end{array}$ \\
\hline $\begin{array}{c}\text { number of years of } \\
\text { teaching } \\
\text { experience }\end{array}$ & $\begin{array}{c}\text { Less than } 3 \\
\text { years } \\
\text { 3-5 years } \\
\text { 6-7 yeas } \\
\text { More than } 7 \\
\text { years }\end{array}$ & $\begin{array}{l}23 \\
41 \\
53 \\
84\end{array}$ & $\begin{array}{l}11.4 \\
20.4 \\
26.4 \\
41.8\end{array}$ \\
\hline Academic level & $\begin{array}{l}\text { B.A degree } \\
\text { MA degree } \\
\text { Ph.D. degree }\end{array}$ & $\begin{array}{c}137 \\
47 \\
17\end{array}$ & $\begin{array}{c}68.2 \\
23.4 \\
8.5\end{array}$ \\
\hline \multicolumn{2}{|l|}{ Total } & 201 & 100.0 \\
\hline
\end{tabular}

\subsection{Instrument of the Study}

The researchers prepared a questionnaire for measuring the estimations of the role of school curricula in enhancing the image of women in Jordanian society. It consisted of seven domains the first domain, "Domains of women's work" included (13) items, the second domain" the role of higher basic stage curricula role in clarifying the woman's legal and professional equality with man" included (16) items, the third, fourth, fifth and sixth domain include "Jordanian curricula role in the higher basic stage in encouraging the woman in politic wok \& equality between males and females in the curricula \& Women environment\& Attitudes in presenting women's image: 
attitudes in presenting the woman's image". Each of them included (5) items, whereas the seventh domain" Attitudes in presenting woman's image" included (12) items.

The instrument included (61) items. It was developed after reviewing the related literature about empowering woman and her image in the school curricula (Islamic religion, Arabic language, national and public education, history, and geography).

\subsection{Validity}

For verifying the instrument of the study, it was judged by a number of specialized specialists, and all their comments were taken into consideration. The items of the questionnaire were modified, eleven items were deleted, and the items left were (61).

\subsection{Reliability}

To verify the reliability of the instrument, the internal harmony was done by Cronbach's alpha, the value for the instrument as a whole was (0.93), whereas the value for the first domain (domains of woman's work) was (0.81). The value for the second domain (the role of higher basic stage curricula role in clarifying the woman's legal and professional equality with men) was $(0.90)$. In contrast, the value for the third domain (Jordanian curricula role in the higher basic stage in encouraging the woman in politic work) was (0.76), for the fourth domain (equality between males and females in the curricula), the value was (0.89), the fifth domain (woman's environment ) was (0.76), the sixth domain (attitudes in presenting the woman's image ) was (0.61), and the seventh domain (Attitudes in presenting woman's image)the value was (0.82). All those percentages were suitable for the purpose of the study.

\subsection{Statistical Procedures}

Cronbach's alpha for the domain and the instrumental as a whole and the validity of the study was done.

Means standard deviations were also done. T. test for the effect of sex on the estimations of the teachers was done too. In addition, One-way ANOVA analysis for the effect of the academic level and age, for teachers on their estimations was also done.

\section{Results \& Discussion}

\subsection{Results Related to the First Question}

"What are the estimations of teachers for the role of the curricula in enhancing the woman's image in the Jordanian community?"
To answer this question, arithmetic averages and standard deviations for the responses of the participants to the seven items of the study's questionnaire were calculated. The following is an explanation of these results:

Table 2. It showed Means and standard deviations of the teacher's estimations for curricula role in enhancing women's image in the Jordanian community

\begin{tabular}{|c|c|c|c|c|}
\hline Rank & Areas & Means & $\mathrm{SD}$ & percentage \\
\hline 1 & $\begin{array}{c}\text { Attitudes in presenting } \\
\text { women's image }\end{array}$ & 2.24 & .47 & 74.6 \\
\hline 2 & Women environment & 2.21 & .53 & 73.8 \\
\hline 3 & $\begin{array}{l}\text { Attitudes in presenting } \\
\text { woman's image }\end{array}$ & 2.00 & .43 & 66.8 \\
\hline 4 & $\begin{array}{c}\text { Jordanian curricula } \\
\text { role in the higher basic } \\
\text { stage in encouraging } \\
\text { the woman in politic } \\
\text { work }\end{array}$ & 1.98 & .54 & 65.8 \\
\hline 5 & $\begin{array}{l}\text { Domains of women's } \\
\text { work }\end{array}$ & 1.97 & 39 & 65.7 \\
\hline 6 & $\begin{array}{l}\text { the role of higher basic } \\
\text { stage curricula role in } \\
\text { clarifying the woman's } \\
\text { legal and professional } \\
\text { equality with man }\end{array}$ & 1.92 & .48 & 64.0 \\
\hline \multirow[t]{2}{*}{7} & $\begin{array}{c}\text { equality between } \\
\text { males and females in } \\
\text { the curricula }\end{array}$ & 1.76 & .65 & 58.67 \\
\hline & $\begin{array}{c}\text { The instrument as a } \\
\text { whole }\end{array}$ & 1.99 & 34 & 66.3 \\
\hline
\end{tabular}

Table (2) shows the mean scores and standard deviations of the teacher's estimations for the role of the curricula in enhancing the woman's image in the Jordanian community. The sixth domain of " Attitudes in presenting women's image " in presenting women's image took the first rank in a mean score of (2.24) and a standard deviation of (0.47).In the second rank, there was the fifth domain "woman's environment" of a mean score of (2.21) and a standard deviation of (0.53). The seventh domain of "Attitudes in presenting woman's image " came in the third rank in a mean score of (2.00) and a standard deviation of (0.43). Whereas the forth domain of "equality between males and females in the curricula" came in the last rank in the lowest mean score (1.76) and a standard deviation of (0.65). The mean score for the instrument as a whole was (1.99) and the standard deviation was (0.34). The following measurement was used to show the strong estimations of the teachers to the role of curricula in enhancing the woman's image (1.5-2 weak estimations), (2- 2.5 medium estimations), (2.5 - 3 high estimations). Through these estimations- the estimations of the teachers were below the average because of the little caring of woman's image in the school textbooks and curricula (Omran 2008, Al nuseirat, 1997). Below is an explanation of the responses of the participants to the items of the questionnaire. 
Table 3. Means and standard deviations for the first domain items that are related to woman's work arranged top - down according to the mean scores

\begin{tabular}{|c|c|c|c|c|}
\hline Rank & Items & means & SD & percentage \\
\hline 1 & $\begin{array}{l}\text { The curricula care about the role of the daughter (the small girl) } \\
\text { more than others. }\end{array}$ & 2.16 & 0.68 & 72.2 \\
\hline 2 & The curricula show the woman as a grandmother. & 2.15 & 0.73 & 71.8 \\
\hline 3 & The curricula focused on the role of the student. & 2.12 & 0.73 & 70.6 \\
\hline 4 & The curricula were restricted only for the role of mother. & 2.10 & 0.73 & 70.0 \\
\hline 5 & $\begin{array}{l}\text { The curriculum strengthens the important role of the woman in the } \\
\text { community. }\end{array}$ & 2.05 & 0.72 & 68.2 \\
\hline 6 & The clear role is the wife. & 2.05 & 0.72 & 68.3 \\
\hline 7 & the curricula show the worker woman more than others. & 2.00 & 0.71 & 66.8 \\
\hline 8 & The curricula clarify the woman's role in the community. & 1.96 & 0.67 & 65.2 \\
\hline 9 & $\begin{array}{l}\text { The Jordanian curricula care in the higher basic stage in woman's } \\
\text { learning. }\end{array}$ & 1.82 & 0.70 & 60.8 \\
\hline 10 & $\begin{array}{l}\text { The Jordanian curricula encourage the activation of woman's role in } \\
\text { the community. }\end{array}$ & 1.82 & 0.72 & 60.5 \\
\hline 11 & $\begin{array}{l}\text { The learning Curricula help in liberating the woman from } \\
\text { inferiority. }\end{array}$ & 1.82 & 0.76 & 60.7 \\
\hline 12 & The Jordanian curricula deal with woman as man's partner. & 1.81 & 0.71 & 60.2 \\
\hline 13 & The curricula enhance the woman's image in the community. & 1.77 & 0.73 & 59.0 \\
\hline
\end{tabular}

Table 4. Means and standard deviations for the second area "the role of the higher basic stage in clarifying the woman's legal and professional side

\begin{tabular}{|c|c|c|c|c|}
\hline rank & Items & means & SD & Percentage \\
\hline 1 & The curricula show the woman's political duties in the community. & 2.19 & .74 & 73.0 \\
\hline 2 & The curricula show the woman's political rights in the community. & 2.12 & .73 & 70.6 \\
\hline 3 & The curricula show the woman's economic duties in the community. & 2.06 & .75 & 68.7 \\
\hline 4 & The curricula show the woman's economic rights in the community. & 2.03 & .73 & 67.7 \\
\hline 5 & The curricula show the woman's health rights in the community. & 1.95 & .76 & 64.8 \\
\hline 5 & The curricula show the woman's health duties in the community. & 1.95 & .74 & 65.0 \\
\hline 7 & The curricula encourage the woman to work. & 1.92 & .74 & 63.8 \\
\hline 8 & In the basic stage, the curricula point at the woman's family role in the community. & 1.89 & .75 & 62.9 \\
\hline 9 & The curricula show the woman's cultural rights in the community. & 1.88 & .75 & 62.5 \\
\hline 10 & The curricula encourage the woman to join higher education. & 1.88 & .77 & 62.7 \\
\hline 11 & The curricula encourage the woman to practice different professions & 1.87 & .77 & 62.4 \\
\hline 11 & The curricula reinforce the role of women in an election. & 1.87 & .77 & 62.2 \\
\hline 13 & The curricula show the woman's educational rights in the community. & 1.80 & .74 & 59.8 \\
\hline 13 & Curricula care to show the woman's effective role in the community. & 1.80 & .72 & 60.0 \\
\hline 15 & The curricula show the women s social rights in the community. & 1.77 & .71 & 59.0 \\
\hline 16 & The curricula reinforce the woman's right in the election. & 1.75 & .78 & 58.4 \\
\hline
\end{tabular}

\section{First Domain: Domains of woman's work}

Table (3) shows the mean scores and the standard deviations of the first Domain items of woman's work domains. Item (11) that implies " the curricula care about the daughter's role (the little girl) more than others" came in the first rank in a mean score of (2.16) and a standard deviation of (0.68); whereas item (6) which implies " the curricula enhance the woman's image in the community " came in the last rank in a mean score of (1.77) and a standard deviation of $(0.73)$.

\section{Second Domain: the role of higher basic stage curricula role in clarifying the woman's legal and professional equality with man.}

Table (4) shows the mean score and the standard deviation for the second domain items, the role of higher basic stage curricula in showing the woman's legal and professional side. Item (20) that implies the curricula showing the woman's political duties in the community came in the first rank having a mean score of (2.19) and a standard deviation of (0.74); whereas item (28) came in the last rank having a mean score of (1.75) and a standard 
deviation (0.78). It implies "the curricula reinforce the woman's right in elections.

\section{Domain three: Jordanian curricula role in encouraging the woman in political work}

Table (5) shows the mean scores and standard deviation of the third Domain items about the role of Jordanian curricula in the higher basic stage in encouraging the woman's political work. Item (31) that implies the curricula care about educating students about woman's rights in elections came in the first rank having a mean score of (2.07) and a standard deviation of (0.73) whereas item (33) came in the last rank in a mean score of (1.88) and a standard deviation of (0.74). It implies the curricula show lessons and ideal characters through the important historical woman in history.

\section{Domain four: equality between males and females in the curricula.}

Table (6) shows the mean score and standard deviations for the fourth Domain items "equality in the curricula between males and females." Item (39) that implies" the curricula put equal standards between males and females" came in the first rank having a mean score of (1.93) and a standard deviation of (0.73). Whereas item (36) that implies "the curricula is equal in the textbooks periods between males and females" came in the last rank having a mean score of (1.62) and a standard deviation of (0.75).

\section{Domain five: Woman's Environment}

Table (7) shows the means and the standard deviations of the fifth Domain items "woman's environment." Item (44) that implies "the curricula never show the woman's housing environment" came in the first rank having a mean score of (2.32) and a standard deviation of (0.71) whereas item (40) came in the last rank in a mean score of (2.05). It implies "the curricula show the woman's city environment".

Table 5. Means and standard deviation for the third area items "curricula in the higher basic stage in encouraging the woman in political work arranged from the highest means

\begin{tabular}{|c|c|c|c|c|}
\hline Rank & Items & Means & SD & Percentage \\
\hline 1 & The curricula care about educating the students about the woman's right in election. & 2.07 & 0.73 & 69.0 \\
\hline 2 & The curricula encourage the woman to be a candidate for the political positions. & 2.02 & 0.76 & 67.3 \\
\hline 3 & The curricula clarify the woman's political rights. & 2.00 & 0.74 & 66.5 \\
\hline 4 & The curricula eliminate all types of discrimination against woman. & 1.92 & 0.79 & 63.8 \\
\hline 5 & $\begin{array}{l}\text { The curricula show lessons and ideal characters through important historic women } \\
\text { in history. }\end{array}$ & 1.88 & 0.74 & 62.5 \\
\hline
\end{tabular}

Table 6. Means and standard deviation for the fourth area items "equality between males and females in the curricula" arranging from the highest means

\begin{tabular}{|c|c|c|c|c|}
\hline Rank & Items & means & SD & Percentage \\
\hline 1 & The school curricula put equal standards between males and females. & 1.93 & .75 & 64.2 \\
\hline 2 & $\begin{array}{l}\text { The school curricula imply equal classroom activities curriculum and non- } \\
\text { curriculum for males and females. }\end{array}$ & 1.78 & .70 & 59.4 \\
\hline 3 & The school curricula give equal chances for males and females. & 1.77 & .77 & 59.0 \\
\hline 4 & The school curricula give equal chances for males and females in textbooks. & 1.69 & .82 & 56.4 \\
\hline
\end{tabular}

Table 7. Means and standard deviations for the fifth Domain items" woman's environment" arranged from the highest means

\begin{tabular}{|c|c|c|c|c|}
\hline Rank & Items & means & SD & Percentage \\
\hline 1 & The curricula never show the woman's housing environment. & 2.32 & .71 & 77.3 \\
\hline 2 & The curricula focused on the woman's environment in the camps. & 2.30 & .75 & 76.6 \\
\hline 3 & The curricula focused on the woman's rural environment. & 2.22 & .78 & 74.0 \\
\hline 4 & The curricula focused on the woman's Bedouin environment. & 2.18 & .75 & 72.6 \\
\hline
\end{tabular}


Table 8. Means and standard of deviations for the fifth area items "attitudes in presenting woman's image arranged from highest means

\begin{tabular}{|c|c|c|c|c|}
\hline Rank & Items & means & SD & Percentage \\
\hline 1 & The curricula show negative qualities about the woman like ignorance. & 2.48 & .71 & 82.8 \\
\hline 2 & The curricula show the woman in careless. & 2.45 & .75 & 81.6 \\
\hline 3 & The curricula show the woman as a dependent. & 2.23 & .79 & 74.3 \\
\hline 4 & The curricula show the role of woman without mentioning positive or negative qualities. & 2.04 & .75 & 68.2 \\
\hline 5 & The curricula show the woman's role as respected and appreciated. & 1.99 & .80 & 66.3 \\
\hline
\end{tabular}

Table 9. Means and standard of deviations for the seventh area items "attitudes in presenting woman's image" arranged from highest means

\begin{tabular}{|c|c|c|c|c|}
\hline Rank & Items & means & SD & Percentage \\
\hline 1 & The role of the woman is restricted only in raising children. & 2.07 & .79 & 69.2 \\
\hline 2 & The curricula show the woman in bringing up creation. & 2.05 & .79 & 68.3 \\
\hline 3 & The curricula show the woman's treatment with her children & 2.03 & .77 & 67.7 \\
\hline 4 & The woman plans for the children's future. & 2.02 & .77 & 67.5 \\
\hline 4 & The curricula show the woman in different professions. & 2.02 & .70 & 67.5 \\
\hline 6 & The curricula show the woman's role in cooperation between wife and husband. & 2.00 & .74 & 66.5 \\
\hline 6 & The curricula show the woman's duty towards citizenship. & 2.00 & .71 & 66.8 \\
\hline 8 & The curricula show the woman as a housewife. & 1.99 & .77 & 66.3 \\
\hline 8 & The curricula show the woman as passionate. & 1.99 & .76 & 66.2 \\
\hline 10 & The curricula mention the distinguished women in Arab history. & 1.98 & .74 & 66.0 \\
\hline 11 & The curricula show the woman in an accepted social image (cooperative. & 1.95 & .67 & 64.8 \\
\hline 12 & The curricula show the woman as an educated person. & 1.93 & .73 & 64.3 \\
\hline
\end{tabular}

\section{Domain six: attitudes in presenting woman's image}

Table (8) shows the mean scores and the standard deviations of the fifth Domain items about attitudes in presenting the woman's image. Item (45) that implies " the curricula show negative qualities about the woman like ignorance" came in the first rank in a mean score of (2.48) and a standard deviation of (0.71) whereas item (48) that implies" The curricula shows the woman's role as respected and appreciate " came in the last rank having a mean score of (I.99) and a standard deviation of (0.80).

\section{The Seventh Domain: Attitudes in presenting woman's image}

Table (9) shows the mean score and standard deviations for the seventh Domain items " attitudes of woman's image" item (52) came in the first rank having a mean score of (2.07) and a standard deviation of (0.79), it implies" the woman's role is only restricted to bringing up children."
Whereas item (54) that implies "The curricula show the woman as educated person." came in the last rank in a mean score of (1.93) and a standard deviation of (0.73).

\subsection{Results Related to the Second Question}

"Are the estimations of higher basic stage teachers in the governorate of Ajloun for the role of higher basic stage curricula in enhancing the woman's picture for the Jordanian community different according to (sex, number of years of teaching experience, educational qualification)?"

\section{First: gender variable (males and females)}

The researchers used the arithmetic averages, standard deviations, and the T-test to identify the impact of gender on teachers' assessments of the role of the curricula in improving the image of women in Jordanian society and table (10) shows that: 
Table 10. Means, standard deviations and T. test for the effect of sex on the teachers' estimations for the role of the curricula.

\begin{tabular}{|c|c|c|c|c|c|c|c|}
\hline & & No. & Means & SD & T. value & Fd & Sig. \\
\hline \multirow{2}{*}{ Domains of woman's work } & Male & 110 & 1.93 & .39 & -1.553 & 199 & .122 \\
\hline & Female & 91 & 2.02 & .39 & -1.554 & 192.423 & .122 \\
\hline \multirow{2}{*}{$\begin{array}{c}\text { the role of higher basic stage curricula role in } \\
\text { clarifying the woman's legal and professional } \\
\text { equality with man }\end{array}$} & Male & 110 & 1.86 & .48 & -1.958 & 199 & .52 \\
\hline & Female & 91 & 1.99 & 47 & -1.962 & 193.534 & .51 \\
\hline \multirow{2}{*}{$\begin{array}{l}\text { Jordanian curricula role in the higher basic stage in } \\
\text { encouraging the woman in political work. }\end{array}$} & Male & 110 & 1.94 & .55 & -.912 & 199 & .363 \\
\hline & Female & 91 & 2.01 & .53 & -.915 & 194.408 & .361 \\
\hline \multirow{2}{*}{$\begin{array}{l}\text { equality between males and females in the } \\
\text { curricula }\end{array}$} & Male & 110 & 1.69 & .62 & -1.765 & 199 & .79 \\
\hline & Female & 91 & 1.85 & .67 & -1.751 & 184.804 & .82 \\
\hline \multirow{2}{*}{ Woman's environment } & Male & 110 & 2.18 & .52 & -.915 & 199 & .361 \\
\hline & Female & 91 & 2.25 & .54 & -.912 & 189.075 & .363 \\
\hline \multirow{2}{*}{ Attitudes in presenting women's image } & Male & 110 & 2.21 & .42 & -.806 & 199 & .404 \\
\hline & Female & 91 & 2.27 & .54 & -.837 & 168.380 & .404 \\
\hline \multirow{2}{*}{ Attitudes in presenting woman's image } & Male & 110 & 1.94 & .40 & -2.144 & 199 & .33 \\
\hline & Female & 91 & 2.07 & .47 & -2.111 & 177.005 & .36 \\
\hline \multirow{2}{*}{ The instrument as a whole } & Male & 110 & 1.94 & .33 & -2.256 & 199 & .25 \\
\hline & Female & 91 & 2.05 & .35 & -2.245 & 188.058 & .26 \\
\hline
\end{tabular}

Table 11. Means, standard deviations and T.test for the effect of the number of years of teaching experience on the Teachers' Estimations on the Role of the Curricula

\begin{tabular}{|c|c|c|c|c|c|c|c|c|}
\hline & \multicolumn{2}{|c|}{ Less than 3 years } & \multicolumn{2}{|c|}{$3-5$ years } & \multicolumn{2}{c|}{$6-7$ yeas } & \multicolumn{2}{c|}{ More than 7 years } \\
\hline & means & SD & means & SD & means & SD & means & SD \\
\hline Woman's work domain & 2.02 & .36 & 1.97 & .41 & 1.93 & 42 & 1.95 & .39 \\
\hline $\begin{array}{c}\text { the role of higher basic stage curricula } \\
\text { role in clarifying the woman's legal and } \\
\text { professional equality with man }\end{array}$ & 1.91 & .51 & 1.93 & .44 & 2.02 & .49 & 1.89 & .49 \\
\hline $\begin{array}{c}\text { Jordanian curricula role in the higher } \\
\text { basic stage in encouraging the woman } \\
\text { in political work. }\end{array}$ & 2.02 & .57 & 1.95 & .55 & 2.10 & .62 & 1.93 & .49 \\
\hline $\begin{array}{c}\text { equality between males and females in } \\
\text { the curricula }\end{array}$ & 1.80 & .65 & 1.70 & .66 & 2.04 & .70 & 1.69 & .61 \\
\hline Woman's environment & 2.25 & .51 & 2.32 & .52 & 2.13 & .60 & 2.15 & .52 \\
\hline $\begin{array}{c}\text { Attitudes in presenting a woman's } \\
\text { image }\end{array}$ & 2.17 & .42 & 2.30 & .47 & 2.22 & .60 & 2.24 & .47 \\
\hline $\begin{array}{c}\text { Attitudes in presenting a woman's } \\
\text { image }\end{array}$ & 1.96 & .35 & 2.05 & .43 & 2.10 & .52 & 1.97 & .45 \\
\hline The instrument as a whole & 1.99 & .34 & 2.00 & .31 & 2.06 & .39 & 1.96 & .35 \\
\hline
\end{tabular}

Table (10) shows that there are no statistically significant differences at the level of $(0.05)$ between male teachers' estimation and female teachers' estimation of the role of curricula in improving the image of women among members of the Jordanian society. The researchers attribute this result to the woman's passion for learning and the empowerment of women in different fields which enable them to analyze the role of the curriculum similarly to men

\section{Second: number of years of teaching experience}

To identify the differences in teachers' assessments of the role of the curriculum in improving the image of women according to the variable number of years of teaching experience, arithmetic averages and standard deviations of participants' responses were calculated, as shown in Table 11.

Table (11) shows apparent variation in the mean scores and the standard deviations of the teacher's estimations for the role of the curricula because of the different number of years of teaching experience (Less than 3 years, 3-5 years, 6-7 yeas, More than 7 years). To find out the statistical difference among the mean scores, One-way ANOVA analysis was done, it is shown in table (12).

It is clear from the table (12) that there were no statistically significant differences at $(\alpha=0.05)$ attributed to the number of years teaching experience variable in all Domains and the instrument as a whole. 
Table 12. One-Way ANOVA Analysis for the effect of the teaching Experience on the Teachers' Estimations for the Curricula Role

\begin{tabular}{|c|c|c|c|c|c|c|}
\hline Variable & Source of variance & $\begin{array}{l}\text { Total of } \\
\text { squares }\end{array}$ & Df & Means of squares & $\mathbf{F}$ & Sig. \\
\hline Woman's work domain & $\begin{array}{c}\text { Within groups } \\
\text { Between groups } \\
\text { Total }\end{array}$ & $\begin{array}{c}.124 \\
30.757 \\
30.881\end{array}$ & $\begin{array}{c}3 \\
197 \\
200\end{array}$ & $\begin{array}{l}.041 \\
.151\end{array}$ & .265 & .851 \\
\hline $\begin{array}{l}\text { the role of higher basic stage } \\
\text { curricula role in clarifying } \\
\text { the woman's legal and } \\
\text { professional equality with } \\
\text { man }\end{array}$ & $\begin{array}{l}\text { Within groups } \\
\text { Between groups } \\
\text { Total }\end{array}$ & $\begin{array}{c}286 \\
46.012 \\
46.298\end{array}$ & $\begin{array}{c}3 \\
197 \\
200\end{array}$ & $\begin{array}{l}.95 \\
.234\end{array}$ & .408 & .747 \\
\hline $\begin{array}{l}\text { Jordanian curricula role in } \\
\text { the higher basic stage in } \\
\text { encouraging the woman in } \\
\text { politic work. }\end{array}$ & $\begin{array}{l}\text { Within groups } \\
\text { Between groups } \\
\text { Total }\end{array}$ & $\begin{array}{c}.672 \\
57.244 \\
57.916\end{array}$ & $\begin{array}{c}3 \\
197 \\
200\end{array}$ & $\begin{array}{l}.224 \\
.291\end{array}$ & .771 & .512 \\
\hline $\begin{array}{l}\text { equality between males and } \\
\text { females in the curricula }\end{array}$ & $\begin{array}{c}\text { Within groups } \\
\text { Between groups } \\
\text { Total } \\
\end{array}$ & $\begin{array}{c}2.488 \\
80.9 \\
83.409 \\
\end{array}$ & $\begin{array}{c}3 \\
197 \\
200 \\
\end{array}$ & $\begin{array}{l}.829 \\
.411\end{array}$ & 2.019 & .113 \\
\hline Woman's environment & $\begin{array}{c}\text { Within groups } \\
\text { Between groups } \\
\text { Total } \\
\end{array}$ & $\begin{array}{c}1.199 \\
54.967 \\
56.166 \\
\end{array}$ & $\begin{array}{c}3 \\
197 \\
200 \\
\end{array}$ & $\begin{array}{l}.400 \\
.279\end{array}$ & 1.432 & .235 \\
\hline $\begin{array}{l}\text { Attitudes in presenting } \\
\text { woman's image }\end{array}$ & $\begin{array}{l}\text { Within groups } \\
\text { Between groups } \\
\text { Total }\end{array}$ & $\begin{array}{c}.417 \\
44.601 \\
45.017\end{array}$ & $\begin{array}{c}3 \\
197 \\
200\end{array}$ & $\begin{array}{l}.139 \\
.226\end{array}$ & .613 & .607 \\
\hline $\begin{array}{l}\text { Attitudes in presenting } \\
\text { woman's image }\end{array}$ & $\begin{array}{c}\text { Within groups } \\
\text { Between groups } \\
\text { Total } \\
\end{array}$ & $\begin{array}{c}481 \\
37.254 \\
37.734 \\
\end{array}$ & $\begin{array}{c}3 \\
197 \\
200 \\
\end{array}$ & $\begin{array}{l}.160 \\
.189\end{array}$ & .848 & .469 \\
\hline The instrument as a whole & $\begin{array}{c}\text { Within groups } \\
\text { Between groups } \\
\text { Total } \\
\end{array}$ & $\begin{array}{c}.216 \\
23.082 \\
23.298 \\
\end{array}$ & $\begin{array}{c}3 \\
197 \\
200 \\
\end{array}$ & $\begin{array}{l}.072 \\
.117\end{array}$ & .614 & .607 \\
\hline
\end{tabular}

Table 13. Means, Standard Deviations and T-Test of the effect of Academic Level on the Teachers' Estimations for the Curricula Role.

\begin{tabular}{|c|c|c|c|c|c|c|}
\cline { 2 - 7 } \multicolumn{1}{c|}{} & \multicolumn{2}{c|}{ B.A degree } & \multicolumn{2}{c|}{ MA degree } & \multicolumn{2}{c|}{ Ph.D. degree } \\
\cline { 2 - 7 } & Means & SD & Means & SD & Means & SD \\
\hline Woman's work domain & 1.96 & .37 & 2.00 & .43 & 2.00 & .47 \\
\hline $\begin{array}{c}\text { the role of higher basic stage curricula role in } \\
\text { clarifying the woman's legal and professional } \\
\text { equality with man }\end{array}$ & 1.91 & .46 & 1.96 & .53 & 1.89 & .55 \\
\hline $\begin{array}{c}\text { Jordanian curricula role in the higher basic stage } \\
\text { in encouraging the woman in political work. }\end{array}$ & 2.00 & .54 & 1.94 & .53 & 1.91 & .61 \\
\hline $\begin{array}{c}\text { equality between males and females in the } \\
\text { curricula }\end{array}$ & 1.77 & .62 & 1.77 & .69 & 1.67 & .71 \\
\hline Woman's environment & 2.26 & .51 & 2.14 & .56 & 2.05 & .58 \\
\hline Attitudes in presenting woman's image & 2.25 & .45 & 2.20 & .56 & 2.26 & .48 \\
\hline Attitudes in presenting woman's image & 2.00 & .42 & 2.00 & .45 & 2.05 & .52 \\
\hline The instrument as a whole & 1.99 & .32 & 1.99 & .34 & 1.97 & .47 \\
\hline
\end{tabular}

\section{Third, the variable of educational qualification}

The arithmetic averages, standard deviations and T-Test were used to identify the differences between the responses of the members of the study sample concerning the role of the curricula in improving the image of women in the Jordanian society according to the variable of the educational qualification, as shown in table (13).

It is clear from table (13) apparent variance in the means and standard deviations of the teachers' estimation for the curricula role because of the different academic level categories (BA degree, MA degree, Ph.D. degree). For showing the statistical significant differences among the mean scores, One-way ANOVA analysis was done. It is shown in table 14.

It is clear from table (14) that there were no statistically significant differences at $(\alpha=0.05)$ attributed to the effect of an academic level variable in all Domains and the instrument as a whole. 
Table 14. One-way ANOVA Analysis for the effect of Academic Level on the Teacher's Estimations for the Curricula

\begin{tabular}{|c|c|c|c|c|c|c|}
\hline Variable & Source of variance & $\begin{array}{l}\text { Total of } \\
\text { squares }\end{array}$ & df & $\begin{array}{c}\text { Means of } \\
\text { squares }\end{array}$ & $\mathbf{F e}$ & Sig. \\
\hline Woman's work domain & $\begin{array}{l}\text { Within groups } \\
\text { Between groups } \\
\text { Total }\end{array}$ & $\begin{array}{c}.64 \\
30.817 \\
30.881\end{array}$ & $\begin{array}{c}2 \\
198 \\
200\end{array}$ & $\begin{array}{l}.32 \\
.156\end{array}$ & .207 & .813 \\
\hline $\begin{array}{l}\text { the role of higher basic stage curricula role } \\
\text { in clarifying the woman's legal and } \\
\text { professional equality with man }\end{array}$ & $\begin{array}{l}\text { Within groups } \\
\text { Between groups } \\
\text { Total }\end{array}$ & $\begin{array}{c}.93 \\
46.205 \\
46.298 \\
\end{array}$ & $\begin{array}{c}2 \\
198 \\
200\end{array}$ & $\begin{array}{l}.47 \\
.233\end{array}$ & .200 & .819 \\
\hline $\begin{array}{l}\text { Jordanian curricula role in the higher basic } \\
\text { stage in encouraging the woman in political } \\
\text { work. }\end{array}$ & $\begin{array}{l}\text { Within groups } \\
\text { Between groups } \\
\text { Total }\end{array}$ & $\begin{array}{l}.196 \\
57.720 \\
57.916\end{array}$ & $\begin{array}{c}2 \\
198 \\
200\end{array}$ & $\begin{array}{l}.98 \\
.292\end{array}$ & .336 & .715 \\
\hline $\begin{array}{l}\text { equality between males and females in the } \\
\text { curricula }\end{array}$ & $\begin{array}{l}\text { Within groups } \\
\text { Between groups } \\
\text { Total }\end{array}$ & $\begin{array}{l}.143 \\
83.266 \\
83.409\end{array}$ & $\begin{array}{c}2 \\
198 \\
200\end{array}$ & $\begin{array}{l}.71 \\
.421\end{array}$ & .170 & .844 \\
\hline Woman's environment & $\begin{array}{l}\text { Within groups } \\
\text { Between groups } \\
\text { Total }\end{array}$ & $\begin{array}{c}.998 \\
55.168 \\
56.166\end{array}$ & $\begin{array}{c}2 \\
198 \\
200\end{array}$ & $\begin{array}{l}.499 \\
.279\end{array}$ & 1.791 & 170 \\
\hline Attitudes in presenting woman's image & $\begin{array}{l}\text { Within groups } \\
\text { Between groups } \\
\text { Total }\end{array}$ & $\begin{array}{c}.75 \\
44.942 \\
45.017\end{array}$ & $\begin{array}{c}2 \\
198 \\
200\end{array}$ & $\begin{array}{l}.37 \\
.190\end{array}$ & .165 & .848 \\
\hline Attitudes in presenting woman's image & $\begin{array}{l}\text { Within groups } \\
\text { Between groups } \\
\text { total }\end{array}$ & $\begin{array}{c}.40 \\
37.694 \\
37.734\end{array}$ & $\begin{array}{c}2 \\
198 \\
200\end{array}$ & $\begin{array}{l}.20 \\
.190\end{array}$ & .106 & .899 \\
\hline The instrument as a whole & $\begin{array}{c}\text { Within groups } \\
\text { Between groups } \\
\text { total }\end{array}$ & $\begin{array}{c}.008 \\
23.291 \\
21.298 \\
\end{array}$ & $\begin{array}{c}2 \\
198 \\
200 \\
\end{array}$ & $\begin{array}{l}.004 \\
118\end{array}$ & .23 & .968 \\
\hline
\end{tabular}

\section{Discussion}

The results of the study (table 3) showed the woman's work domains according to their importance- from the samples of the study point of view- came as the following, the daughter woman (little girl) grandmother, student, and mother's role.

This result agrees with the past studies in showing the role of the woman in the curricula as a traditional one such as Abu-Ayyash (2019) ; Gadri, R., et al (2015); Sarabi (2010); ALKhaldi (2004), which show the role of woman either a daughter or a grandmother.

Also, Al Assali (2005) showed that the textbooks concentrated on showing the woman as a daughter and wife.

These roles which the curricula reflect for the woman put her in a traditional way, which does not suit her, or suit her high mission in building the society and the family, and does not help the curricula allowing the woman to do the wanted role which is forming a cultured generation depending on justice, equality and equal opportunities, consequently improving the society's image towards woman.

Table (4) results show the role of higher basic stage curricula, in displaying the woman's legal and professional side, according to the estimations of the study sample, it was between mid and low rank also according to the role of curricula in encouraging the woman in the political work (table 5).

Perhaps the reason is to be found in the normal roles that the curricula shows for the woman as a mother-daughter and grandmother, which is reflected on woman's legal and professional side. Also in table (6) the role of curricula in implying equality rank between males and females came in the last rank according to the teacher's point of view. The curricula show the woman's normal environment (table), it emphasis on the camps, rural and Bedouin environment. In contrast, the roles of women in the city environment came in the last rank.

The curricula present the woman's image according to negative qualities, which shows negative characteristics of woman like ignorance, careless and dependent (table 8),

This result agrees with Omran study (2008), which shows that the curricula contribute to a lack of awareness of woman's position and rights; this developed feeling of desperation, negativity or maybe inferiority complex.

Also it agrees with (Gadri, et al (2015), which shows a humble contribution to the woman in the political side, and this is because the school curricula do not encourage the woman to practice the political work.

This may be because of the Jordanian's societal image towards the woman that she is only born to bring up the creation and obey the husband.

The Jordanian society is a traditional society and the normal image of woman still prevailing in the society that the tribal and sectarian system are still ruling the political and sociable relationships, preventing a single person from exceeding this system and keeping his feeling and behavior captive to it.

And perhaps this matter reflects on the school curricula content or the teacher's views, to the point that the curricula contributed in improving the woman's image in Jordanian 
society.

The researcher traces that there is no statistically significant differences or academic qualifications on the teacher's estimations on the role of the curricula in the Jordanian society .as in table (12) and table (14), it is clear that the curricula is weak in showing the woman's image in the traditional shape, which does not need a clearly defined high academic level or academic experience for discovering this normal image and curricula partiality to man.

This may be because the teachers believed in the importance of the woman's role in building the society and creating the expected cultural and social change. That's what made the difference between the teachers mean scores according to the experience and academic qualifications insignificant so that it didn't have statistical indications

\section{Conclusions}

Our perception of ourselves is the result of our interaction with social, educational, and real-life experiences. The awareness of these experiences forms perceptions concerning our rights, duties, capabilities, and capabilities. Curricula consist of educational experiences that aimed at developing the individual socially, psychologically, mentally, and physically, and thus curricula play a key role in forming the perceptions towards women. Controversy still exists regarding the role of the curricula in affecting these perceptions. Do they reflect the perceptions of the society, or do they reform new perceptions? It is crystal clear that the school curricula are capable of forming the minds of students, whether curricula reflect the reality or they reform it.

It is noted from the results of the current study that the curriculum for the basic upper stage still revels stereotypical images of women, and the role of these curricula in improving the image of women in Jordanian society is still below average. The majority of women are still deprived of their legal and civil rights and from participating in social life except. Besides, the occupations that a woman can occupy in society for Jordan are limited. Many Jordanians still believe that women should stay at home, and if they work, they should work in traditional and socially acceptable professions.

\section{REFERENCES}

[1] Abu-Ayyash , I. (2019). Woman in the New Palestinian Curriculum: Arabic Language Curriculum as a Model. Journal of Social Sciences. (9), 60-75.

[2] Abu Odeh, A. (2010). Measurement and evaluation in the teaching process, Irbed: Dar Al-Amal for Publishing and Distribution

[3] Al Khaldi, N. (2004). The Role of School Curriculum in Empowering the Jordanian Woman unpublished MA thesis university of Jordan, Amman, Jordan.

[4] Al Neserat, F. (1997). The Woman's Image in Arabic Textbook for the Secondary Stage in Jordan. Unpublished MA Thesis. University of Jordan, Amman; JORDAN.

[5] Department of Statistics. (2018). Jordan statistical year book, Amman: Department of Statistics.

[6] Fahmi, M. (2003). Social and Political Participation for the Woman in the Third World. Al Eskandariyah. Modern University Office. ed.(1), p 123 .

[7] Gadri, R., Affouneh, S., Qadan, A., Sheriadeh, M.,al saad, R.,Jizmawi,S., ketaneh, N., et al.. (2015). Women Image in Grade Eight Textbooks. An-Najah University Journal: (Humanities), 29(5), 866-894. Doi: 10.35552/0247-029-005 $-003$

[8] Shetewi, M., \& Al Daghistani, A. (1994). Woman and Political Participation Strategic Studies Center. University of Jordan, Amman: Jordan.

[9] Kabeer, N. (1999). resources, agency, achievement, reflection on the measurement of woman's empowerment, in development and change. 30(45). year7thm apr.2010. www.ulum.nl. Human science magazine.

[10] Omran, S. (2008). Woman in Learning Curricula. Abu Reesha, Zaleekha. The Absent Language. Towards a non Gender Language. Woman Studies Center: Amman 1996.

[11] Sarabi, S. (2010). The Image of Women in Jordanian School Books, Damascus University Journal, $26(1+2)$, 463-496.

[12] United Nations Development Fund for Woman, Western Asia office (UNESEF)(1999).The Explorer in Gender and Development. Reference booklet, Amman, Jordan. 